Arfel, G., and Fischgold, H. (1961). Electroencephalography and Clinical Neurophysiology, 13, 653

Bickford, R. G., Dawson, B., and Takeshita, H. (1965). Electroencephalography and Clinical Neurophysiology, 18, 513.

Bickford, R. G., and Klass, D. W. (1966). In Head Injuries ed. W. F. Caveness and A. E. Walker, p. 63. Philadelphia, Lippincott.

Binnie, C. D., Margerison, J. H., and Whitehead, M. K. (1966). Electroencephalography and Clinical Neurophysiology, 21, 309.

Chase, T. N., Moretti, L., and Prensky, A. L. (1968). Neurology (Minneapolis), 18, 357.

Chatrian, G. E., White, L. E., and Shaw, C. M. (1964). Electroencephalography and Clinical Neurophysiology, 16, 285 .

Haider, I., Oswald, I., and Matthew, H. (1968). British Medical Fournal, 3,314 .

Hockaday, J. M., Potts, F., Epstein, E., Bonazzi, A., and Schwab, R. S. (1965). Electroencephalography and Clinical Neurophysiology', 18, 575.
Jouvet, M. (1959). Electroencephalography and Clinical Neurophysiolugy, $11,805$.

Loeb, C., and Poggio, G. (1953). Electroencephalography and Clinical Neurophysiology, 5, 295.

Lundervold, A., Hauge, T., and Löken, A. C. (1956). Electroencephalography and Clinical Neurophysiology, 8, 665.

Pampiglione, G. (1962). Proceedings of the Royal Society of Medicine, 55, 653. Pampiglione, G., and Harden, A. (1968). Lancet, 1, 1261.

Prior, P. F., and Volavka, J. (1968). Electroencephalography and Clinical Neurophysiology, 24, 593 .

Rossoff, S. D., and Schwab, R. S. (1968). Electroencephalography and Clinical Neurophysiology, 24, 283.

Silverman, D., Saunders, M. G., Schwab, R. S., and Masland, R. L. (1969).

Fournal of the American Medical Association, 209, 1505.
Whelan, J. L., Webster, J. E., and Gurdjian, E. S. (1955). Elcctroencephalography and Clinical Neurophysiology, 7, 495.

\title{
Immunity, Transferrin, and Survival in Kwashiorkor
}

\author{
H. McFARLANE, ${ }^{*}$ PH.D., M.R.C.PATH. ; S. REDDY, $†$ M.B., B.S., M.R.C.P.ED. ; K. J. ADCOCK, $\ddagger$ M.B., B.S., D.R.C.o.G. \\ H. ADESHINA, $\$ A.M.I.L.T. ; A. R. COOKE, $\ddagger$ M.B., B.S., D.T.M. \& H. ; J. AKENE
}

\begin{abstract}
Gummary: In a study of 40 children with kwash$\checkmark$ iorkor, serum albumin, transferrin, and immunoglobulin levels were measured. Treatment included chloroquine, pyrimethamine, multivitamins, folic acid, iron compounds, and a high-protein diet. After two weeks the mean serum transferrin values in the children who survived and those who died were $1.30 \mathrm{mg} . / \mathrm{ml}$. and $0.33 \mathrm{mg} . / \mathrm{ml}$., respectively. Many of the children died immediately after treatment started, and it is suggested that in children with severe kwashiorkor and low serum transferrin levels any increase in free-circulating iron may result in overwhelming infection and death. Thus the appropriate time for instituting iron therapy in such patients should be reconsidered.
\end{abstract}

\section{Introduction}

In kwashiorkor assessment of the degree of malnutrition or its prognosis on clinical grounds alone is universally accepted as being difficult. Hence several attempts have been made to find suitable biochemical tests to fulfil this need (Waterlow et al., 1960). The low serum transferrin levels found in kwashiorkor may be significant (Antia et al., 1968) and of several biochemical tests McFarlane et al. (1969) found the serum transferrin to be the most accurate index for assessing kwashiorkor.

Infection is more prevalent in this disease than in the rest of the population (Scrimshaw et al., 1960), and there is evidence of an immune deficiency state in kwashiorkor. Brown and Katz (1965), in Uganda, noted that the serum immunoglobulin concentration in kwashiorkor was severely depressed, whereas Najiar et al. (1969) observed high serum IgG, IgA, and IgM in marasmic infants with no clinical evidence of kwashiorkor. On the other hand, mean levels of serum immunoglobulin values in both severe and moderate kwashiorkor did not show much difference (McFarlane et al., 1970), though some individual kwashiorkor children had reduced serum immunoglobulin values. We report here the results of the Heaf test and a sequential study of

\footnotetext{
* Late Professor of Chemical Pathology, University of Ibadan. Present address: Department of Chemical Pathology, Manchester University, Manchester, England.

† Head of General Outpatients.

Senior Hospital Medical Officer, General Outpatient Department.

$\$$ Senior Technician.

II Laboratory Assistant (Research).

University College Hospital, Ibadan, Nigeria.
}

albumin, transferrin, and immunoglobulins in children with kwashiorkor.

\section{Patients and Methods}

Of the 40 children studied with kwashiorkor, who were attending the general outpatient clinic of University College Hospital, Ibadan, 21 were girls and 19 boys aged $1 \frac{1}{2}$ to 5 years. Of these seven had hepatomegaly, one of whom also had splenomegaly; only one child was jaundiced; and almost all had varying degrees of diarrhoea, two having malaria. Ascaris ova were found in the stools of two children. Clinical evidence of bacterial infection was found in four childrentwo had otitis media, one had conjunctivitis and one had furunculosis.

The Heaf test was done with the standard technique and was negative in all cases. No abnormality was detected on routine chest $x$-ray examination. Twenty-nine were haemaglobin genotype AA. All the children were treated initially with chloroquine and thereafter with weekly doses of pyrimethamine; a multivitamin mixture plus $5 \mathrm{mg}$. of folic acid was given daily. The children were given a high-protein diet in the form of milk powder that was known to have a high-protein content. Sulphadimidine and potassium chloride were prescribed for those with diarrhoea, and the bacterial infections noted above were treated with antibiotics as indicated. Oral ferrous sulphate was prescribed for most of those who had low packed cell volume after the diarrhoea had subsided. When oral iron was not available intramuscular iron was given. Most of the children were followed up for six weeks or more, though many died or dropped out of the study. All were seen every other day during the first two weeks and thereafter once or twice a week, depending on the severity of the illness.

Serum proteins were estimated by the method of Gornall $e t$ al. (1949), serum uric acid by the method of Feichtmeir and Wrenn (1955), and serum transferrin and immunoglobulins by the Hyland immunoplate method.

\section{Results}

\section{Serum Albumin and Serum Transferrin}

The time course sequence of albumin and transferrin concentration in the children with kwashiorkor who survived and 
in those who died is shown in Fig. 1. The mean albumin values are plotted on the same semilogarithmic scale as the transferrin values for ease of comparison. The serum albumin patterns were similar when plotted on linear paper. Before treatment began the mean serum albumin values of children who survived was similar to that of those who died, whereas there was a pronounced initial difference in the mean serum transferrin value between these two groups (Fig. 1).

The initial mean serum transferrin value in those who survived was twice as high as in those who were lost to followup and three times as high as in those who subsequently died. After treatment the difference between the groups became even greater, and at the end of two weeks the mean serum transferrin value in those who survived $(1.3 \mathrm{mg} . / \mathrm{ml}$.) was about four times higher than in those who eventually died $(0.33 \mathrm{mg} . / \mathrm{ml}$.). In comparison the mean serum albumin concentration in those who died was $1.6 \mathrm{~g} . / 100 \mathrm{ml}$. and in those who recovered $2.2 \mathrm{~g} . / 100 \mathrm{ml}$.

Most patients who were responding to treatment showed an appreciable rise in the serum transferrin level even as early as the second day after treatment and a twofold to fourfold increase by the fourth day. Most probably the rise in the serum transferrin concentration on the second day was not more pronounced because of the redistribution of body fluids caused by the loss of oedema. In fact in some patients the serum transferrin values fell noticeably by the second day but in those who survived the values usually promptly increased again by the thind to the fourth day of treatment.

The pattern of the transferrin results in four children who initially had low serum transferrin values is shown in Fig. 2. Immediately after treatment had started (phase 1) the serum transferrin value fell significantly, which seemed to last for about 24 to 48 hours. This was followed by phase 2, starting on the third day, when a very sharp rise occurred, reaching a peak between the sixth and eighth day. During the second week of treatment (phase 3) there was a pronounced fluctuation in the levels. This was followed by phase 4 , which continued after the third week with values showing less fluctuation. The serum albumin in these four children did not show such pronounced changes. The serum transferrin values were mostly in the upper limit of the normal range, whereas for the corresponding period the serum concentrations of albumin were in the lower limit of the normal range.

Patients Who Died.-Only 2 of the 13 patients who died had serum transferrin values above $0.4 \mathrm{mg} . / \mathrm{ml}$. before treatment. The percentage increase after treatment was negligible

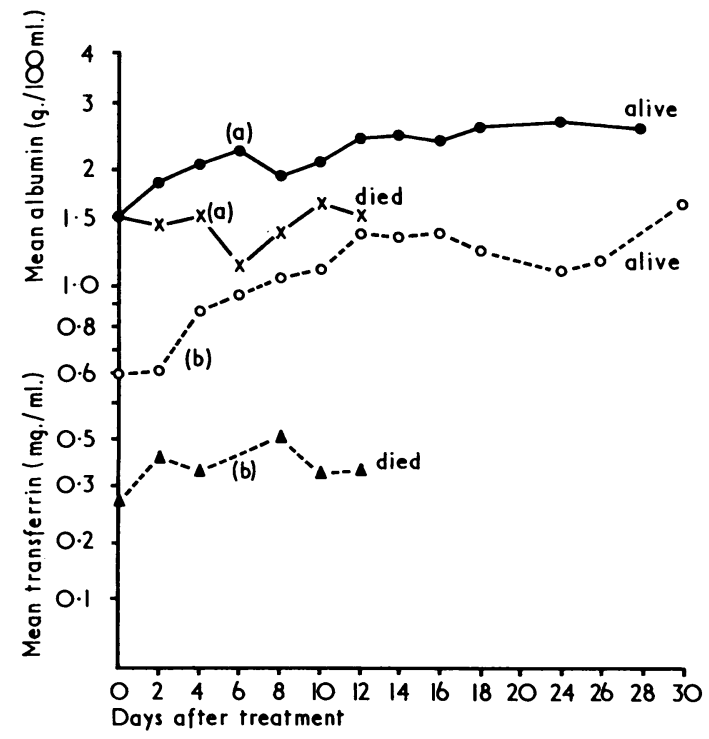

FIG. 1.-Difference between serum albumin (a) and transferrin (b) in kwashiorkor children who survived and in those who died. Note the pronounced difference in the transferrin values. in most of those who eventually died. Just before death, most of them had values of less than $0.33 \mathrm{mg} . / \mathrm{ml}$. Two who died by the second day after they were first seen had values of 0.32 and $0.22 \mathrm{mg} . / \mathrm{ml}$. and two others who died on the fourth day had values of 0.21 and $0.3 \mathrm{mg} . / \mathrm{ml}$.

Children Lost to Follow-up.-Of the 11 children who were lost to follow-up by the end of the second week of the study all but one had initial serum transferrin values of less than $0.4 \mathrm{mg}$. $/ \mathrm{ml}$. Nine had initial values ranging from 0.038 to 0.38 $\mathrm{mg} . / \mathrm{ml}$., and none had appreciably increased transferrin values after four days of treatment. The prognosis was generally unfavourable if the serum transferrin still remained less than $0.45 \mathrm{mg} . / \mathrm{ml}$. after four to seven days of treatment. Thus the most probable reason for their dropping out was death.

\section{Serum Immunoglobulins}

The serum immunoglobulin patterns showed pronounced variations. The IgG concentrations ranged from 10 to 40 $\mathrm{mg} . / \mathrm{ml}$., IgA from 0.8 to $4 \mathrm{mg} . / \mathrm{ml}$., and IgM from 0.6 to 2 $\mathrm{mg} . / \mathrm{ml}$. As in our previous studies (McFarlane et al., 1970), a few children had low serum immunoglobulin levels and a few high levels, but most of the values were similar to those in age-matched controls. One child, who had diarrhoea and otitis media and eventually died, had a low serum IgG throughout.

\section{Serum Uric Acid}

Serum uric acid was in no way related to the nutritional state, and the patterns were similar in those who survived and those who died.

\section{Discussion}

The serum albumin results did not give any guide to the subsequent progress of the child with kwashiorkor. The mean values of those who died and of those who survived were not significantly different. Interestingly all three serum
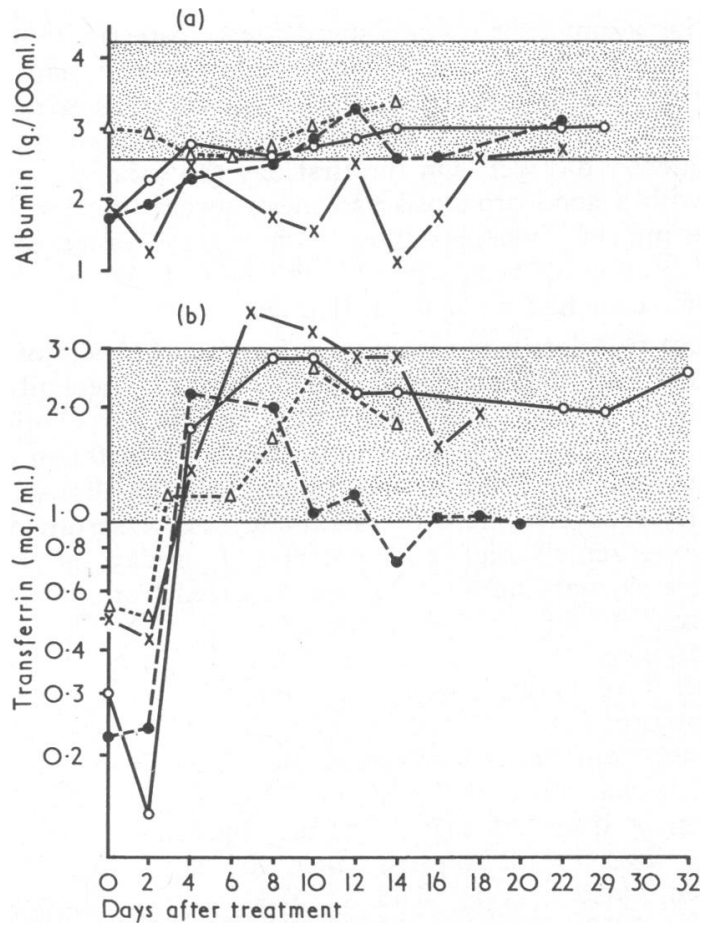

Fig. 2.-Comparison of values of serum albumin (a) and transferrin (b) in 4 children who survived. The shaded areas represent the normal range. 
immunoglobulin (IgC, $\operatorname{IgA}$, and $\operatorname{IgM}$ ) levels were not generally affected by lack of protein intake. Mean values were mostly similar in those who died and in those who survived. Some patients showed an increase in concentration of these immunoglobulins after corrective treatment but this was not the rule. In three children the serum IgG concentration rose immed tately before death, and in an unpublished study (McFarlane et al., 1967) about 10 to $20 \%$ of children with kwashiorkor had IgG values above $30 \mathrm{mg} . / \mathrm{ml}$. The reason for this is not clear, but the high serum IgG may be related to infection. Cohen and Hansen (1962) showed that four children with kwashiorkor with signs of infection also had high rates of $\gamma$-globulin synthesis. Four children had reduced levels of $\operatorname{IgA}$ throughout, but this appeared to be related to their ages rather than to any abnormality in synthesis or catabolism. Most children had normal serum IgM during the six weeks or more of treatment, though occasionally the IgM was slightly reduced in a few. Watson and Freesemann (1970) suggested that the high initial levels of immunoglobulins in kwashiorkor may be a response to infection. Diarrhoea in almost all the children may also be an indication of infection, which is known to be prevalent in malnutrition.

The negative Heaf test in all the children could be regarded as evidence of impairment of the cell-mediated immune response which is known to exist in kwashiorkor. In Ibadan, J. A. Idowu (personal communication, 1970) stated that 5 to $15 \%$ of normal children under 5 years usually show a positive Heaf test. Lloyd (1968) noticed a depression of the Heaf test in children with malnutrition, and Watts (1969) declared that the atrophied thymus of the kwashiorkor child is the most likely cause of the impaired cell-mediated immune response. Hutt (1969) stated that in malnourished children not only are the Heaf and Mantoux reactions depressed but also the conversion rate after B.C.G. vaccination. Studying the serum immunoglobulins in pulmonary tuberculosis in Nigeria, Malomo et al. (1970) found that most of the Mantoux-negative subjects were undernourished children.

Plasma uric acid levels did not show any constant abnormal patterns. A few children initially had high values which quickly reverted to normal on treatment. In some children the serum uric acid concentration increased after treatment had begun but later returned to pretreatment values.

Of the serum proteins measured the transferrin showed the most remarkable changes. Those children who had a poor prognosis had considerably lower mean transferrin values before, during, and after initiating treatment than those who subsequently did well. On the first day the children were seen those with a good prognosis had mean serum transferrin levels of $0.76 \mathrm{mg} . / \mathrm{ml}$, , whereas those with a grave prognosis had a mean value of $0.29 \mathrm{mg} . / \mathrm{ml}$. By the end of the second week this difference had risen about fivefold.

Serum transferrin is responsible for the transport of iron in the body and under normal conditions only negligible concentrations of iron are found free in the circulation. An estimation of the mean total intravascular transferrin mass in four kwashiorkor children who responded well showed that in the early recovery phase the synthetic rate of serum transferrin was extremely high and that after four days of treatment the intravascular transferrin mass increased from about 175 to $1,000 \mathrm{mg}$. At this time, however, the mean serum transferrin concentration of $2 \mathrm{mg} . / \mathrm{ml}$. in these children can bind an equivalent of about $3.4 \mu \mathrm{g}$. of iron, which far exceeds the concentration of iron found in their serum. On the other hand, the transferrin levels of those who did not respond to treatment was about $0.32 \mathrm{mg}$. $/ \mathrm{ml}$. This could bind only about $0.55 \mu \mathrm{g}$. of iron and may leave an appreciable concentration of free iron in the plasma since the serum iron in these children ranged from 0.48 to $0.80 \mu \mathrm{g} . / \mathrm{ml}$. Edozien and Udeozo (1960) observed that in kwashiorkor the percentage saturation of the total iron-binding capacity was generally above the normal range. Using an in-vitro technique, Schade
(1963, 1966) showed that serum transferrin has a bacteriostatic action and that iron-requiring pathogenic bacteria like Staphylococcus aureus, Shigella paradysenteriae, and Pseudomonas aeruginosa will grow more readily in sera which contain an excess of free iron caused by oversaturation of the available transferrin than in sera which contain all the iron bound to transferrin.

At death children with kwashiorkor have acute bacterial infections, and Soltys and Brody (1970) remarked that the occurrence of Gram-negative sepsis in certain conditions in which the concentration of free transferrin is diminished implies that this iron-binding protein may be a component of an auxiliary antibody-globulin system. Barber (1961) suggested that iron-free transferrin prevents the formation of lipid peroxides, which are known to be toxic to several biological systems.

Interestingly a high percentage of the children with kwashiorkor died immediately after treatment had started. The only constant finding among them was the greatly reduced transferrin. Unfortunately it was not possible to determine the exact cause of death of these children as necropsies were not done. Conceivably in children with severe kwashiorkor and low serum transferrin any increase of the serum iron, particularly during the first week of treatment, from whatever source, may encourage bacterial infections since all the available serum transferrin is of the bound type. The free iron would then be available to promote bacterial growth (Rogers, 1967), resulting in overwhelming infection and finally death. Further studies are in progress to elucidate this mechanism, but it may be therapeutically sound to reconsider the appropriate time at which iron therapy is instituted in these patients. The haemosiderosis which is so often seen in kwashiorkor at necropsy may be the result of the low serum transferrin and increased free circulating iron.

We should like to thank the University of Ibadan for a Senate Research Grant to conduct these studies.

\section{REFERENCES}

Antia, A. U., McFarlane, H., and Soothill, J. F. (1968). Archives of Disease in Childhood, 43, 459.

Barber, A. A. (1961). Archives of Biochemistry and Biophysics, 92, 38.

Brown, R. E., and Katz, M. (1965). East African Medical fournal, 42, 221.

Cohen, S., and Hansen, J. D. L. (1962). Clinical Science, 23, 351.

Edozien, J. C., and Udeozo, I. O. K. (1960). Fournal of Tropical Pediatrics and African Child Health, 6, 60.

Feichtmeir, T. V., and Wrenn, H. T. (1955). American fournal of Clinical Pathology, 25, 833. Gornall, A. G., Bardawill, C. J., and David, M. M. (1949). Fournal of
Biological Chemistry, 177, 751.

Hutt, M. S. R. (1969). Fournal of Tropical Pediatrics, 15, 153.

Lloyd, A. V. C. (1968). British Medical fournal, 3, 529.

McFarlane, H., et al. (1969). Lancet, 1, 392.

McFarlane, H., et al. (1970). Tropical and Geographical Medicine, 22, 61.

Malomo, I. M., McFarlane, H., and Idowu, J. A. (1970). Transactions of the Royal Society of Tropical Medicine and Hygiene, 64. In press.

Najiar, S. S., Stephan, M., and Asfour, R. Y. (1969). Archives of Disease in Childhood, 44, 120.

Rogers, H. J. (1967). Immunology, 12, 285.

Schade, A. L. (1963). Biochemische Zeitschrift, 338, 140.

Schade, A. L. (1966). In Proceedings of the Colloquium on the Protides of the Biological Fluids, ed. H. Peeters, vol. 14, p. 13. Amsterdam, Elsevier.

Scrimshaw, N. S., Wilson, D., and Bressani, R. (1960). Journal of Tropical Pediatrics and African Child Health, 6, 37.

Soltys, H. D., and Brody, J. I. (1970). Fournal of Laboratory and Clinical Medicin, , 75, 250.

Waterlow, J. C., Cravioto, J., and Stephen, J. M. L. (1960). Advances in Protein Chemistry, 15, 131. Watson, C. E., and Freesemann, C. (1970). Archives of Disease in Childhood,
45, 282.

Watts, T. (1969). Fournal of Tropical Pediatrics, 15, 155. 